\title{
Pilkada Langsung: Kisah Sukses dan Problematika
}

\author{
Teten Jamaludin ${ }^{1}$ \\ Dewan Kehormatan Penyelenggara Pemilu (DKPP) RI, Jakarta - Indonesia
}

\begin{abstract}
The implementation of direct local election has become important part of Indonesian society. This election is achievement of the reform. The public can finally vote for their head of the region (the local leaders) based on their own aspiration. The mechanism of this local election is somehow facing pro and contra between direct and indirect. It is considering the positive and negative impacts of the mechanism. The positive impact is to provide an opportunity for proposing their own people of the region to be candidate. This opportunity as a constitutional right of citizen regardless of race, ethnicity, and religion. Other results that there are number of regions are developed since this direct election able to produce several local leaders who are innovative and creative in developing their regions. In contrary, not few of the regional head are entangled with corruption cases. This is caused by the high cost of politics to achieve the seat of that regional head and co-head of the region. In addition, the cost to run the local election is also extremely expensive. Besides the local election socially triggers the horizontal conflict especially among the regional elites and its supporters. Different from the indirect local election that the cost is less. However, its has shortcoming that the regional head elected are not directly reflecting the aspirations of its people.
\end{abstract}

Pelaksanaan Pemilihan Kepala Daerah (Pilkada) langsung telah menjadi bagian dari masyarakat Indonesia. Pilkada ini merupakan buah dari reformasi. Masyarakat bisa menentukan sendiri kepala daerahnya sesuai dengan aspirasinya. Mekanisme pemilihan kepala daerah ini mengalami pro dan kontra antara langsung dan tidak langsung. Hal tersebut mengingat dari dampak positif dan negatifnya dari mekanisme tersebut. Dampak positif adalah memberikan kesempatan kepada putra daerah untuk mencalonkan. Kesempatan tersebut sebagai hak konstitusional warga negara tanpa mengenal suku, ras, dan agama. Dan hasil lainnya adalah, ada sejumlah daerah yang maju karena Pilkada langsung menghasilkan pemimpin daerah yang inovatif dan kreatif dalam mengembangkan daerah-daerahnya. Sisi negatifnya, tidak sedikit kepala daerah yang terjerat dengan kasus korupsi. Hal ini disebabkan oleh mahalnya ongkos politik untuk meraih kepala daerah maupun wakil kepala daerah. Selain itu, biaya penyelenggaraan pelaksanaan Pilkada juga sangat terlampau mahal. Secara sosial, pelaksanaan Pilkada rawan konflik horizontal terutama dari para elit daerah dan pendukungnya. Ada pun Pilkada tidak langsung cost yang dikeluarkan sangat sedikit. Namun kekurangannya, kepala daerah yang terpilih tidakmencerminkan aspirasi langsung dari rakyatnya.

Keywords: direct local election; indirect local election; coruption; expensive

1Korespondensi: Teten Jamaludin (teten.jamaludin1981@gmail.), staff ahli Dewan Kehormatan Penyelenggara Pemilu (DKPP) RI, Jl. M.H. Thamrin No. 14 Jakarta Pusat 10240 - Indonesia. 


\section{Pendahuluan}

Runtuhnya Orde Baru memuncul wacana agar daerah mendapat kesempatan untuk mengurus rumah tangga sendiri. Wacana ini dampak dari zaman kebijakan Orde Baru yang sangat sentralistik. Setiap kebijakan selalu ditentukan oleh Pusat sementara peran daerah hanya pasif. Terjadinya penyeragaman antara kebijakan satu daerah dengan daerah yang lain dengan mengesampingkan eksistensi kearifan lokal yang dimiliki oleh tiap-tiap daerah. Kekayaan hanya tersentralisasi di pusat. Disparitas antara pusat dengan daerah yang semakin jauh. Daerahdaerah yang kaya akan sumber daya alam tidak bisa menikmati potensi dan kekayaan yang dimilikinya. Daerah-daerah yang melimpah ini seperti tikus yang mati di lumbung padi dan hanya kebagian kerusakan hasil eksploitasi pemerintah pusat.

Begitu juga secara politik. Peran pemerintah pusat begitu dominan. Untuk menentukan kepala daerah saja harus dari Pusat. Masyarakatnya tidak bisa memilih kepala daerahnya sendiri. Tumbangnya Orde Baru dan berganti menjadi era reformasi menjadi kesempatan bagi daerah untuk menyuarakan aspirasinya. Muncul suara-suara sumbang dari daerah yang ingin lepas dari NKRI. Terbitlah Undang-Undang 22 tahun 1999 tentang Pemerintahan daerah sebagai jawaban atas pergolakan di daerah. Undang-Undang tersebut sebagai hasil dari proses dialektika antara negara kesatuan dengan negara federal seperti Malaysia.

Ada dua alasan yang kuat munculnya undangUndang No. 22 tahun 1999 tentang Pemerintahan Daerah atau lebih dikenal dengan Undang-Undang Otonomi Daerah (Haris 2014). Dalam bidang pemerintahan, Undang-Undang tersebut sebagai pendidikan politik. Artinya, yang memerintah adalah putra daerah yang memang mengetahui secara langsung kebutuhan dari daerah tersebut. Sekaligus mengembangkan sumber daya manusia (SDM) yang ada di daerahnya. Kedua, pelatihaan kepemimpinan nasional. Para kepala daerah yang berprestasi dari daerahnya masing-masing berpotensi untuk menjadi kepala daerahnya setingkat di atasnya. Misalnya, kepala daerah yang berprestasi di tingkat kabupaten/kota, memiliki kesempatan mencalonkan kepala daerah di tingkat provinsi bahkan sampai tingkat pusat, menteri atau presiden misalnya. Ketiga, adalah stabilitas politik. Diharapkan undang-undang ini mampu meredam setiap gejolak terutama daerah-daerah yang selama Orde Baru dirugikan. Undangundang ini diharapkan menjadi jawaban atas segala tuntutan dan aspirasi dari masyarakat di daerah.

Ada pun bagi pemerintah daerah, tujuan dari Undang-undang No. 22 Tahun 1999 adalah; pertama; kesamaan politik. Tiap-tiap daerah memiliki hak yang sama dalam mengembangkan daerahnya sesuai dengan potensi baik sumber daya alam dan sumber daya manusia yang dimilikinya. Kedua, tanggung jawab publik. Pemerintah daerah berkewajiban untuk mempertanggungjawabkan kinerja kepada masyarakatnya. Dan masyarakat pun berhak menilai pemerintahnya dalam Pemilu. Ketiga, daya tangkap pemerintah daerah dalam meningkatkan pelayanan. Pelayanan pemerintah terhadap masyarakat menjadi semakin dekat. Undangundang ini juga memiliki peranan dalam: (a) pengaturan check and balances antar institusiinstutusi pemerintah; (b) kebebasan berpartisipasi secara efektif di kalangan warga negara khususnya dalam kebebasan berorganisasi dan menyatakan pendapat (Haris 2003).

Dalam menentukan kepala daerah, setiap putra daerah memiliki kesempatan untuk mencalonkan dan dicalonkan menjadi kepala daerah. Undang-Undang No. 22 Tahun 1999 menjamin. Undang-undang tersebut memberikan kewenangan kepada DPRD sesuai dengan tingkatannya untuk memilih kepala daerahnya secara 
demokratis. Hal ini sebagaimana dalam Pasal 34 ayat 1 menyebutkan bahwa pengisian jabatan Kepala Daerah dan Wakil Kepala Daerah dilakukan oleh DPRD melalui pemilihan secara bersamaan. Pada ayat (2) calon kepala daerah dan calon wakil kepala daerah ditetapkan oleh DPRD melalui tahap pencalonan dan pemilihan.

Pada pasal 40 ayat (1), (2), dan (3) menerangkan teknis pemilihan. Ayat (1), pemilihan kepala daerah dan wakil kepala daerah dilaksanakan secara langsung, bebas, rahasia, jujur, dan adil. Ayat (2) setiap anggota DPRD dapat memberikan suaranya kepada satu pasang calon kepala daerah atau calon wakil kepala daerah dari pasangan calon yang telah ditetapkan oleh pimpinan DPRD sebagaimana dimaksud dalam Pasal 37 ayat (4); dan ayat (3) Pasangan calon kepala daerah dan calon wakil kepala daerah yang memperoleh suara terbanyak pada pemilihan sebagaimana dimaksud pada ayat (2), ditetapkan sebagai ekpala daerah dan wakil kepala daerah oleh DPRD dan disahkan oleh Presiden.

Kelebihan dari sistem pemilihan tidak langsung adalah ongkosnya yang murah. Tidak perlu badan khusus untuk menyelenggarakan pemilihan. Lebih cepat, efektif dan efisien. Tidak perlu ada mobilisasi masyarakat ke TPS, sehingga masyarakat bisa mengerjakan apa yang menjadi rutinitas. Akan tetapi, disamping kelebihan sistem pemilihan tidak langsung ini memiliki banyak kekurangan. Partai pemenang Pemilu Legislatif belum tentu bisa secara otomatis kandidat yang diusungnya menjadi kepala daerah bisa menang. Terlebih bila tidak ada suara mayoritas di DPRD. Pemilihan Presiden dan Wakil Presiden tahun 1999 adalah salah satu contohnya. Pemilihan Umum tahun 1999 tidak menghasilkan kekuatan politik mayoritas di Parlemen. PDI Perjuangan sebagai pemenang Pemilu. Perolehan suara 33,8\% suara atau 153 kursi, Partai Golkar 22,5\% (120 kursi), PKB mendapat 12,6\% (51 kursi), PPP mendapat 10,7\% (59 kursi), dan PAN 7,1\% (35 kursi).
Dalam pemilihan Presiden, calon dari PDI Perjuangan Megawati hanya 313 suara. Dia kalah oleh Abdurrahman Wahid dari koalisi partaipartai, yang mendapat 373 suara (Koirudin 2005, 112).

Kondisi serupa juga terjadi pada pemilihan kepala daerah di tingkat Provinsi dan kabupaten/kota. Berdasarkan Undang-Undang No. 3 Tahun 1999 tentang Pemilihan Umum (Pemilu), Pasal 5 ayat (1) menyebutkan bahwa jumlah kursi anggota DPRD I (provinsi) ditetapkan sekurang-kurangnya 45 (empat puluh lima) dan sebanyak-banyaknya 100 (seratus) jumlah kursi anggota DPRD I. Sedangkan untuk tingkat kabupaten/kota menurut Pasal 6 ayat (1), jumlah kursi anggota DPRD II (kabupaten/kota) ditetapkan sekurang-kurangnya 20 (dua puluh) dan sebanyak-banyaknya 45 (empat puluh lima). Pemilihan kepala daerah tidak langsung sangat berpotensi terjadinya money politic. Pasalnya, jumlah pemilik suara hanya sedikit. Calon kepala daerah bisa membeli suara.

Pada praktiknya memang demikian. Terjadi ketidaksesuaian atau distorsi antara keinginan elit dengan masyarakat yang diwakilinya. Bagi calon-calon kepala daerah yang akan bersaing, untuk mendapatkan dukungan dari legislatif ia harus "pandai merayu" bila perlu membeli suara. Bahkan praktik politik dagang sapi pun terjadi. Jumlah pemilik suara yang tidak terlalu banyak sehingga akan dengan gampang dikendalikan. Sedangkan bagi anggota legislatif, pemilihan kepala daerah sebagai panen untuk mengeruk keuntungan. Suara-suara aspirasi masyarakat bisa dengan mudah diabaikan. Di sinilah terjadi distorsi antara elit dengan masyarakat.

Berangkat dari latar belakang di atas, artikel ini akan dikaji dengan menggali efek positif dari Pilkada langsung sekaligus dampak negatifnya. Tulisan ini sekaligus mencari solusi dari pelaksanaan Pilkada langsung. Penulisan ini menggunakan metoda kualitatif dengan teknik pengumpulan data dari media atau (media review) 
yang bersumber dari internet dan mencari sejumlah literatur-literatur yang berhubungan dengan tulisan.

\section{Berkah Pilkada Langsung}

Pada masa pasca-reformasi, Undang-Undang No. 22 Tahun 1999 direvisi menjadi UndangUndang No. 32 Tahun 2004. Terjadi perubahanperubahan yang signifikan pada undang-undang tersebut. Perubahan yang paling progresif adalah mekanisme pemilihan kepala daerah. Dari semula tidak langsung, atau dipilih oleh DPRD (legislatif) menjadi pemilihan kepala daerah langsung. Rakyat secara langsung yang menentukan kepala daerahnya melalui mekanisme pemilihan di tempat pemungutan suara (TPS).

Setiap warga memiliki hak untuk dipilih dan memilih. Ini adalah sebuah upaya dalam mengembalikan kedaulatan pada rakyat sebagai pemilik kedaulatan.

Pemilihan kepala daerah langsung ini tidak lepas dari kesuksesan penyelenggaraan Pemilihan Presiden dan Wakil Presiden yang juga dilaksanakan secara langsung pada tahun 2004, akibat traumatis Pemilu sebelumnya. Pemilihan Presiden secara langsung ini sekaligus memperkuat sistem presidensil. Menurut Varney, sebagaimana dikutip oleh Sumanto (2004) ciri utama sistem pemerintahan presidensial adalah: a) kekuasaan eksekutif tidak terbagi (sole eksekutif). Jabatan kepala negara (head of the state) sekaligus kepala pemerintahan (head of government); b) tidak ada peleburan antara eksekutif dan legislatif. Majelis tidak dapat berubah menjadi parlemen dan presiden tidak dapat membubarkan majelis atau parlemen; c) eksekutif bertanggung jawab terhadap konstitusi dan secara langsung kepada pemilih atau rakyat.

Sistem pemilihan langsung juga memiliki kelebihan dibandingkan dengan sistem perwakilan atau tidak langsung. Pertama, pemilihan kepala daerah secara langsung memberikan legitimasi yang sangat kuat dari masyarakat bagi kepala daerah yang terpilih. Kedua, karena memiliki legitimasi langsung dari rakyat, kepala daerah dan wakilnya tidak terikat oleh partaipartai di legislatif. Kepala daerah dan wakilnya tidak bisa dimakzulkan oleh legislatif.

Ketiga, pemilihan kepala daerah langsung memberikan kesempatan luas kepada masyarakat untuk memberikan penilaian langsung kepada calon-calon. Mereka yang benar-benar berkualitas di mata rakyat, merekalah yang bakal dipilih. Keempat, sistem pemilihan langsung oleh rakyat akan mengurangi distorsi. Rakyat bisa langsung menilai dan memutuskan calon yang akan dipilih di tempat pemungutan suara (TPS). Kegagalan Megawati dalam pemilihan presiden tahun 1999 mencerminkan kentalnya distorsi suara rakyat. Kelima, pemilihan langsung oleh rakyat diyakini akan mengurangi praktik politik uang dibandingkan dengan sistem pilihan oleh legislatif yang jumlahnya relatif terbatas (Sumanto 2004, 33).

Hal serupa juga disampaikan oleh Lili Romli bahwa selain mendapatkan mandat langsung dari rakyat dan mendapatkan legitimasi yang sangat kuat, kelebihan dari sistem pemilihan secara langsung adalah: a) sistem ini mampu memutus politik oligarki yang dilakukan oleh sekelompok elit dalam penentuan kepala daerah; b) memperkuat checks and balances dengan DPRD; c) menghasilkan kepala daerah yang akuntabel; d) mampu menghasilkan kepala daerah yang lebih peka dan responsif terhadap tuntutan rakyat (Romli 2008, 1).

Undang-undang otonomi daerah ini mampu menampilkan wajah daerah-daerah sesuai dengan kekhasannya masing-masing. Daerah yang mampu menampilkan keberhasilan-keberhasilan baik bisa diuku secara kuantitatif maupun kualitatif. Keberhasilan-keberhasilan buah dari kebijakan desentralisasi ini bisa diukur dengan beberapa indikator. Ada empat faktor untuk mengukur keberhasilan sebuah daerah. Pertama, kemampuan daerah dalam mengatur tata kelola 
organsisasi. Unit-unit bekerja seseuai dengan tugas dan fungsinya masing-masing dalam menjalankan roda organisasi pemerintahan.

Kedua, kemampuan aparatur pemerintah daerah. Profesionalisme pegawai dalam melayani masyarakat, kepatuhan, dan kedisiplinan dalam menjalankan aturan. Atau lebih tepatnya adalah peningkatan kinerja pemerintah daerah. Kinerja yang diharapkan dalam menjalankan otonomi daerah adalah sebagai berikut (Haris 2014, 105): 1) Pemahaman secara benar terhadap makna atau filosofi dari otonomi daerah. Hal ini dapat dilihat dari kemampuan untuk memahami dan menafsirkan filosofi dan prinsipprinsip otonomi daerah secara benar dan bukan hanya didasarkan pada pembenaran terhadap kelompok kepentingan tertentu. 2) Pemahaman dan penerapan secara menyeluruh terhadap tata kelola pemerintahan yang baik (good governance). Ada sepuluh prinsip tata kelola pemerintahan yang baik berkembang di Indonesa. Meski ini adalah prinsip yang normatif, namun layak untuk menjadi pedoman. Prinsip-prinsip tersebut adalah partisipasi masyarakat, penegakan hukum dan aturan, transparansi, kesetaraan, daya tanggap, wawasan ke depan, akuntabilitas, pengawasan, efisiensi dan efektivitas, dan profesionalisme. 3) Pemahaman dan penerapan yang baik terhadap berfungsi, tugas, kewajiban, dan tanggung jawab. Seseorang yang akan dapat menampilkan kinerja yang baik jika dapat memahami kedudukan, fungsi, dan tugasnya, serta mengetahui dan menyadari tanggung jawabnya dengan baik. 4) Pemahaman yang baik terhadap kondisi, kebutuhan, aspirasi atau tuntutan, dan kepentingan masyarakat. Eksekutif menguasai segala kondisi daerah, dan masyarakatnya, kebutuhan masyarakat, aspirasi dan tuntutan masyarakat. Menjalankan kebijakan sesuai dengan kebutuhan masyakatanya bukan berdasarkan kepentingan kelompoknya. 5) Perhatian dan tanggung jawab terhadap taraf hidup dan kesejahteraan masyarakat. Adanya perhatian dan rasa tanggung jawab dari eksekutif terhadap peningkatan taraf hidup dan kesejahteraan masyarakat akan mendorong eksekutif untuk menampilkan yang terbaik dalam penyelenggaraan pemerintahan.

Ketiga, kemampuan mendorong masyarakat agar berpartisipasi. Mereka dilibatkan dalam kebijakan publik, dan memberikan masukan atau feed back atau kebijakan yang telah diambil oleh pemerintah. Proses kebijakan tidak hanya top down, tetapi juga bottom up. Terakhir, tolok ukur yang paling urgen, yaitu anggaran dalam menjalankan roda pemerintahan. Dari mulai menghasilkan, mengelola, hingga pemanfaatan anggaran tersebut untuk kesejahteraan rakyat.

Sementara itu menurut Oswar Mungkasa sebagaimana dikutip Muhammad Zaenuddin, ada tujuh indikator untuk mengukur keberhasilan suatu daerah. Pertama, adanya jumlah penurunan jumlah kemiskinan. Kedua, kualitas sumber daya manusia (SDM). Ketiga, pemenuhan hak dasar. Menurunnya jumlah siswa yang putus sekolah, kualitas layanan kesehatan yang meningkat dengan tingginya angka harapan hidup. Keempat, lapangan kerja yang luas dan berkurangnya angka pengangguran. Kelima, pembangunan infrastruktur seperti jalan, penerangan dan air minum. Keenam, pemberdayaan ekonomi. Terakhir, kualitas pengelolaan pemerintahan yang baik (Zainuddin 2015).

Berdasarkan kriteria di atas, ada sejumlah daerah yang berhasil maju dibandingkan dengan sebelumnya. Daerah Provinsi Riau misalnya. Daerah yang sempat menyuarakan ingin lepas dari Indonesia ini memiliki potensi alam minyak bumi dan gas yang melimpah. Daerah yang beribu kota di Pekanbaru ini mampu menghasilkan minyak mentah per hari kisaran 500.000 per-barel. Di luar migas Riau juga sukses mengembangkan potensi perkebunan kepala sawit. Dengan luas perkebunan sawit mencapai 3.381 juta per hektar, Riau mampu menjual 2,8 juta ton sawit atau setara dengan 11 triliun di 
tahun 2004 dan meningkat menjadi 3,380 juta ton sawit atau 24 triliun di tahun 2005. Pendapatan asli daerah (PAD) Riau sendiri tidak kalah fantastis dibandingkan dengan daerahdaerah liannya. Pada awal perkembangan otonomi daerah di tahun 1998/199 saja Riau telah berhasil mencapai PAD Rp. 94 miliar, meningkat menjadi Rp. 504 di tahun 2002. Sedangkan dana perimbangan Riau sendiri tidak kurang dari Rp. 215 miliar di tahun 1998/199 dan mengalami pergerakan peningkatan secara signifikan menjadi Rp. 971 miliar di tahun 2003 (Maesarini 2016).

Keberhasilan Riau, diikuti juga oleh daerahdaerah lain. Daerah kaya akan potensi alam itu seperti Provinsi Kalimantan Timur. Daerah ini sangat kaya dengan minyam bumi dan tambang batu bara. Dalam APBD-nya daerah yang beribu kota di Samarinda ini, mendapatkan anggaran pendapatan sebesar Rp. 2,233 trilyun pada tahun 2005. Kontribusi yang didapat dari PAD-nya sendiri tidak kurang dari Rp. 698 miliar sedangkan dana perimbangan sebesar Rp. 1,535 trilyun (Maesarini 2016).

Keberhasilan dan kemajuan daerah tidak hanya tergantung pada hasil eksploitasi dari sumber daya alam an sich. Namun daerah yang memiliki sumber daya alam yang terbatas akan tetapi mampu menjadi daerah yang maju berkat inovatif dan kreativitas kepala daerahnya. Kabupaten Jembrana di Provinsi Bali. Daerah ini PAD-nya hanya Rp. 11 miliar ditambah dengan APBD sebesar 339,3 miliar di tahun 2006, namun mampu meningkatan kesejahteraan penduduknya yang berjumlah 262.058 jiwa. Hal ini tidak lepas dari kebijakan kepala daerahnya pada waktu itu I Gede Winasa, yang mampu melakukan terobosan-terobosan seperti melakukan penghematan anggaran, dengan merampingkan jumlah dinasnya dan dialokasikan kepada pelayanan umum tertuama dalam bidang kesehatan dan program pendidikan dasar bagi usai sekolah secara gratis. Keberhasilan pendidikan gratis di daerah tersebut juga kemudian dicontoh oleh daerah-daerah lain. Jembrana juga dinilai berhasil dalam pelayanan administratif dan manajemen instansi melalui program satu atap (one stop service) sebagai komitmennya dalam melakukan pelayanan prima terhadap masyarakat (Maesarini 2016).

Keterbatasan sumber daya alam menimpa pada Kabupaten Lamongan. Akan tetapi hasil kerja keras Bupati H Masfuk, Kabupaten Lamongan ini mampu menampilkan wajah daerah yang baru. Kabupaten Lamongan yang dikenal dengan kota soto ini berhasil mendapatkan lima kali penghargaan dalam ajang Otonomi Award 2007. Daerah ini juga berhasil meraih Adipura Bangun Praja tahun 2007 sebagai kota terbaik dalam mengelola lingkungan perkotaan. Masfuk juga mampu menampilkan daerah yang maju pada bidang perdagangan, industri pariwisata dan investasi tahun 2008 dan mendapatkan perhargaan Regional Trade, Tourism, and Invesment (RTTI) Award tahun 2008. Ia berhasil mengembangkan industri pariwisata di daerahnya.

Keberhasilan di Kabupaten Jembrana dan Kabupaten Lamongan sejalan dengan yang dijelaskan oleh Siti Zuhro, peneliti LIPI. Dia menerangkan, keberhasilan suatu daerah tidak lepas dari peran kepala daerah. Seorang kepela daerah yang mampu melakukan terobosanterobosan kebijakanlah yang dianggap berhasil dan sesuai untuk mencapai tujuan utama otonomi daerah. Tujuan otonomi daerah antara lain meningkatkan kualitas dan kuantitas pelayanan publik, dan kesejahteraan rakyat. Selain itu, menciptakan efisiensi dan efektivitas pengelolaan sumber daya daerah, memberdayakan dan menciptakan ruang baik masyarakat untuk berpartisipasi dalam proses pembangunan (Subroto dan Akhmad 2013). Seorang kepala daerah sangat menentukan terhadap maju atau mundurnya sebuah daerah. 
Undang-undang otonomi daerah ini pula telah melahirkan pemimpin-pemimpin daerah yang berprestasi. Prestasi tersebut didasarkan pada terobosan-terobosan (breaktrough) kebijakan yang populis. Selain itu, inovasi-inovasi kebijakan-kebijakan dalam mengembangkan daerah yang tidak terjadi pada era Orde Baru.

Majalah Tempo tahun 2008 merilis kepala daerah-kepala daerah yang berhasil memimpin daerahnya. Mereka adalah: 1) Jusuf Serang Kasim, wali Kota Tarakan. Pria yang sebelumnya berprofesi sebagai dokter ini menyulap Tarakan dari kota sampah menjadi "Litte-Singapura" dalam waktu sepuluh tahun. Sebelum era otonomi, Jusuf mengaku tak ubahnya seorang satpam yang hanya melaksanakan perintah atasan. 2) Untung Sarono Wiyono Sukarno, bupati Sragen. Ia mampu melakukan terobosan dengan memanfaatkan teknologi informasi dengan menghubungkan semua desa di Kabupaten Sragen, Jawa Tengah, dengan jaringan internet. Di tangan pengusaha minyak dan gas itu efisiensi pemerintahan meningkat pesat. 3) Joko Widodo atau biasa disapa Jokowi, walikota Solo. Pria yang sebelum menjabat sebagai kepala daerah itu sebagai tukang kayu ini mampu mendemonstrasikan bagaimana memanusiakan warganya. Ketika harus memindahkan pedagang kaki lima, ia lebih dulu mengundang makan para pelaku sektor informal itu. Ia tak memilih jalan pintas: mengerahkan aparat atau membakar lokasi. Setelah undangan makan yang ke-54, baru ia yakin pedagang siap dipindahkan. Acara pemindahan meriah, lengkap dengan arak-arakan yang diramaikan pasukan keraton. Para pedagang gembira ria, mereka menyediakan tumpeng sendiri. 4) Herry Zudianto, walikota Yogyakarta. Ia mendapat julukan "Wagiman" alias "walikota gila taman". Ia membeli lahanlahan kosong hanya untuk taman. Hasilnya sungguh menawan. Yogya terasa segar, karena taman bertambah dari 9 menjadi 22 hektare. 5) Ilham Arif Sirajuddin, walikota Makasar. Pira berusia 43 tahun itu manyulap Lapangan Karebosi yang biasa dipakai oleh para waria pada malam hari menjadi ruang terbuka untuk publik. Ia yakin, warga Makassar perlu lebih banyak ruang terbuka. Ia dilawan, didemo, tapi ia tahu bahwa kepentingan publik nomor satu. Lapangan kumuh dan kerap direndam banjir itu akhirnya menjelma menjadi tempat yang megah tanpa kehilangan label sebagai tempat rendezvous penduduk. 6) Djarot Saiful Hidayat, Blitar. Ia memulai pekerjaan dengan mereformasi birokrasi yang tambun dan lamban. la tak mengganti mobil dinasnya, Toyota Crown tahun 1994, sejak hari pertama menjabat. 7) David Bobihoe meruntuhkan pagar rumah dinasnya di Kota Limboto, ibu kota Kabupaten Gorontalo. Pos jaga ia ratakan dengan tanah. Tamu dari mana saja bebas duduk-duduk di teras rumah, tanpa terhadang aturan protokol ketat. Dia rajin berkeliling daerah, mendengar kemauan orang banyak. la sukses mengajak rakyat membangun, menanam jagung, dan mengekspor hasilnya. 8) Anak Agung Gde Agung, bupati Badung, Bali. Ia punya masalah berat: ekonomi penduduk timpang. Di daerah selatan, Kuta dan sekitarnya, masyarakat makmur karena pariwisata. Tapi petani di utara miskin. Sekolah pertanian ia bangun. Agrobisnis dikembangkan. Ia berhasil. Badung sekarang sanggup menyumbangkan sebagian pendapatan untuk enam kabupaten lain di Bali. 9) Andi Hatta Marakarma, bupati Luwu Timur. Ia menghadapi daerah pemekaran dengan potensi bagus tapi miskin prasarana. Ia membangun desa, termasuk jalan, dan membiarkan kantornya sangat sederhana. Resepnya jitu. Ekonomi rakyat berkembang. "Dulu ongkos angkut satu karung gabah Rp. 9.000, sekarang hanya Rp. 2.000," kata salah seorang ketua kelompok tani di Luwu. 10) Bupati Jombang Suyanto mengundang dokter-dokter spesialis berpraktek di puskesmas. Protes datang dari instansi kesehatan karena ia dinilai melecehkan dokter spesialis. Ia jalan terus dan sekarang 
puskesmas menyandang tingkatan ISO. Ia juga menggratiskan sekolah sampai sekolah lanjutan atas. "Pemimpin itu tak perlu cerdas sekali. Yang penting lurus hati, mulai berpikir sampai berbuat," ujar bupati yang mengaku hanya menghabiskan Rp. 40 juta untuk pemilihan kepala daerah itu.

Selain disebutkan di atas, kepala daerahkepala daerah lain yang berhasil dalam mengelola daerahnya seperti Walikota Bandung Ridwan Kamil, Walikota Surabaya Tri Rismaharini (Risma), dan lain-lain. Ridwan Kamil berhasil mengubah wajah Kota Bandung yang lebih hijau dan tertata. Selama kepemimpinannya, Kota Bandung meraih dua kali penghargaan Adipura. Ia juga berhasil meraih Urban Leadership Award dari Universitas Pensylvania pada tahun 2013.

Ada pun prestasi Risma pernah empat kali meraih piala Adipura kategori Kota Metropolitan secara berturut-turut pada tahun 2011, 2012, 2013, dan 2014. Ia juga berhasil mengantarkan Kota Surabaya sebagai kota terbaik partisipasinya se-Asia Pasifik versi Citynet tahun 2012. Pada tahun 2013, meraih Future Government Award 2013 tingkat Asia Pasifik di bidang Data Center dan Iklusi Digital, yang memanfaatkan teknologi informasi sebagai sentral masukan, dan keluhan masyarakat atas pelayanan pemerintah. Risma pun dinobatkan sebagai Mayor of the Month atau walikota terbaik di dunia pada Pebruari 2014 berkat keberhasilannya memimpin Kota Surabaya sebagai kota Metropolitan. Tahun berikutnya, Word City Mayors Foundation menganugrahi Risma sebagai walikota terbaik ketiga di dunia. Risma dinilai berhasil mengubah wajah Kota Surabaya yang tadinya kumuh menjadi lebih hijau dan rapi dan menjadi masuk jajaran tokoh-tokoh yang berpengaruh di dunia versi Fortune.

Otonomi daerah itu pun mampu memberikan jawaban atas kegelisahan di daerah yang etnis beragam dan aneka agama. Seorang Cornelis yang beragama Katolik bisa menjadi kepala daerah Kalimantan Barat yang mayoritas beragama Islam. Begitu juga Basuki Tjahya Purnama atau biasa disapa Ahok yang beretnis China bisa menjadi Wakil Gubenur DKI Jakarta mendampingi Joko Widodo dan belakang menjadi Gubernur DKI Jakarta yang mayoritas Betawi dan Jawa. Hal serupa juga dengan Gatot Pujo Nugroho yang bersuku Jawa menjadi kepala daerah di Sumatera Utara yang mayoritas penduduk Melayu dan Batak.

Regenerasi kepemimpinan yang menjadi tujuan utama otonomi daerah berjalan dengan baik. Joko Widodo, berkat prestasinya sebagai walikota Solo, dia bisa menjadi Gubernur DKI Jakarta, dan kemudian menjadi orang nomor satu di Indonesia.

Undang-Undang 32 tahun 2004 pun mengalami revisi menjadi Undang-Undang 12 tahun 2008 tentang perubahan kedua atas UndangUndang 32 tahun 2004. Mekanisme pemilihan kepala daerah tetap diserahkan kepada rakyat. Undang-undang tersebut menyatakan bahwa (1) kepala daerah dan wakil kepala daerah dipilih dalam satu pasangan calon yang dilaksanakan secara demokratis berdasarkan asas langsung, umum, bebas, rahasia, jujur dan adil; (2) pasangan calon sebagai dimaksud pada ayat (1) diusulkan oleh partai politik, gabungan partai politik, atau perseorangan yang didukung oleh sejumlah orang yang memenuhi sebagaimana ketentuan dalam undang-undang ini.

\section{Pilkada Langsung dan Problematika yang Melingkupinya}

Ada anekdot yang mengatakan bahwa negeri ini adalah negeri Pilkada. Adalah wajar bila memiliki stigma itu. Pasca Undang-Undang No. 32 Tahun 2004 Tentang Pemerintah Daerah, yang merupakan revisi dari Undang-Undang No 22 Tahun 1999 tentang Otonomi Daerah, Pilkada langsung menjadi rutinitas. Sejak Juni 2005 hingga Desember 2014, negeri ini telah melaksana- 
kan Pilkada langsung sebanyak 1.027 kali. Rinciannya, sebanyak 64 Pilkada Gubernur dan Wakil Gubenur, 776 Pilkada Bupati dan Wakil Bupati, dan sebanyak 187 Pilkada Walikota dan Wakil Walikota. Dari jumlah 1.027, dalam setahun rerata dilaksanakan sebanyak 2,8 kali atau dibulatkan 3 kali. Atau membutuhkan waktu tiga tahun berturut-turut untuk melaksanakan Pilkada. Dalam kurun waktu lima tahun seseorang bisa memilih sebanyak lima kali pencoblosan. Pertama dia memilih kepala desa. Kedua, kepala daerah bupati dan wakil bupati/walikota. Sebagaimana kita ketahui, belum ditambah dengan pelaksanaan Pilkada serentak sebanyak 269 yang dilaksanakan tahun 2015, dan pelaksanaan Pilkada serentak tahun 2017 sebanyak 101.

"Sukses stories" seleksi kepemimpinan melalui produk Undang-Undang No. 32 Tahun 2004 ini pun seolah linier dengan sejumlah problematika yang melingkupi khususnya hasil seleksi pemilihanan kepala daerah langsung. Menteri Dalam Negeri Gamawan Fauzi mengungkapkan bahwa sebanyak 290 kepala daerah sudah berstatus sebagai tersangka, terdakwa, dan terpidana karena tersandung kasus. Dari jumlah tersebut, sebanyak 251 orang kepala daerah atau 86,2\% terjerat kasus korupsi.

Baik Undang-undang No.32 kemudian direvisi menjadi UU No. 12 Tahun 2008 ini memiliki sejumlah kekurangan khususnya yang terkait dengan pelaksanaan pemilihan kepala daerah baik di tingkat provinsi maupun kabupaten/kota.

\section{Mahalnya Pelaksanaan Pilkada}

Banyaknya kepala daerah yang tersandung hukum ini memiliki garis linier dengan ongkos biaya politik. Menurut Kepala Biro Humas Bank Indonesia Difi A. Johansyah, diperkirakan belanja untuk Pilkada 2010 mencapai Rp. 4,2 trilyun dari total 244 Pilkada yang diselenggarakan selama tahun 2010 (Dianto 2013). Apa yang dirilis oleh Bank Indonesia itu hampir sejalan dengan kalkulasi oleh Komisi Pemilih Umum. Anggota KPU RI I Gusti Putu Artha, menerangkan, khusus untuk KPU dan Panwas, KPU kabupaten/kota tahun 2010 menganggarkan sekitar Rp. 7 miliar sampai Rp. 10 miliar. Sedangkan KPU provinsi menganggarkan sekitar Rp. 50 miliar sampai Rp. 70 miliar. Dari sisi Panwas, dana yang dibutuhkan sekitar Rp. 3 miliar untuk tingkat kabupaten/kota dan Rp. 20 miliar untuk tingkat provinsi. KPU sebagai leading sector dalam pelaksanaan pemilihan umum menghitung biaya anggaran pemilhan umum kepala daerah tahun 2010-2014 mencapai Rp. 15 triliun. Ada lima komponen biaya Pilkada. Pertama, dilihat dari pengeluaran KPU. Kedua, Panitia Pengawas Pemilu. Ketiga, kepolisian. Keempat, calon kepala daerah. Dan terakhir, tim kampanye (Tim Liputan Kompas 2010).

Salah seorang yang hendak mencalonkan diri menjadi seorang kepala daerah tidak bisa secara cuma-cuma. Baik UU No. 32 maupun yang telah direvisi, seorang calon kepala daerah dan wakil kepala daerah diusulkan oleh partai politik dan gabungan partai politik. Untuk mendapatkan dukungan, ia harus membeli "perahu". Semakin tinggi levelnya semakin besar pula jumlah "mahar" yang harus dibayar oleh seorang bakal calon. Menteri Dalam Negeri Gamawan Fauzi menilai, ada yang sangat paradoks antara biaya yang Pilkada yang mahal dengan tuntutan pemerintahan yang bersih dari korupsi, kolusi dan nepotisme. Kata dia, untuk menjadi seorang gubernur dibutuhkan dana yang sangat besar, sekitar Rp. 100 miliar, sedangkan gaji gubernur hanya sebesar Rp. 8,7 juta per bulan(Tim Liputan Kompas 2010). Ada pun ongkos yang harus dikeluarkan oleh calon untuk kepala daerah tingkat kabupaten-kota adalah Rp.10-50 miliar. 
Tabel 1.

Sejumlah Nama Kepala Daerah yang Tersandung Hukum

\begin{tabular}{|c|c|c|c|c|}
\hline No. & $\begin{array}{c}\text { Nama } \\
\text { Kepala Daerah }\end{array}$ & Asal & Status & Perkara \\
\hline 1 & Syamsul Arifin & $\begin{array}{l}\text { Gubernur } \\
\text { Sumatera Utara }\end{array}$ & Terpidana & $\begin{array}{l}\text { Korupsi Anggaran Pendapatan } \\
\text { dan Belanja Negara Kabupaten } \\
\text { Langkat tahun 2000-2007 }\end{array}$ \\
\hline 2 & Awang Faroek Ishak & $\begin{array}{l}\text { Gubernur } \\
\text { Kalimantan Timur }\end{array}$ & Tersangka & $\begin{array}{l}\text { Kasus divestasi saham PT Kaltim } \\
\text { Prima Coal. }\end{array}$ \\
\hline 3 & Agusrin Najamudin & $\begin{array}{l}\text { Gubernur } \\
\text { Bengkulu }\end{array}$ & Terpidana & $\begin{array}{l}\text { Korupsi pajak bumi dan } \\
\text { bangunan serta bea penerimaan } \\
\text { hak atas tanah dan bangunan } \\
\text { Bengkulu tahun } 2006-2007\end{array}$ \\
\hline 4 & Thaib Armaiyn & $\begin{array}{l}\text { Gubernur Maluku } \\
\text { Utara }\end{array}$ & Tersangka & $\begin{array}{l}\text { Kasus korupsi Dana Tak Terduga } \\
\text { tahun } 2004 \text { dan APBD Provinsi } \\
\text { Maluku Utara tahun } 2007\end{array}$ \\
\hline 5 & Amran Batalipu & Bupati Buol & Terdakwa & $\begin{array}{l}\text { Terdakwa kasus suap } \\
\text { kepengurusan hak guna usaha } \\
\text { perkebunan kelapa sawit PT } \\
\text { Hardaya Inti Plantations atau PT } \\
\text { Cipta Cakra Murdaya } 2011\end{array}$ \\
\hline 6 & $\begin{array}{l}\text { Mochtar } \\
\text { Muhammad }\end{array}$ & Walikota Bekasi & Terpidana & $\begin{array}{l}\text { Kasus suap dana Anggaran } \\
\text { Pendapatan dan Belanja Negara } \\
2010\end{array}$ \\
\hline 7 & Sunaryo & $\begin{array}{l}\text { Wakil Walikota } \\
\text { Cirebon }\end{array}$ & Terpidana & $\begin{array}{l}\text { Kasus penyelewengan dana } \\
\text { belanja barang dan jasa senilai } \\
\text { Rp. 4,9 miliar dalam APBD Kota } \\
\text { Cirebon } 2004\end{array}$ \\
\hline 8 & Eep Hidayat & Bupati Subang & Terpidana & $\begin{array}{l}\text { Kasus korupsi biaya pemungutan } \\
\text { pajak bumi dan bangunan senilai } \\
\text { Rp. } 14 \text { miliar tahun 2005-2008 }\end{array}$ \\
\hline 9 & Satono & $\begin{array}{l}\text { Bupati Lampung } \\
\text { Timur }\end{array}$ & Terpidana & $\begin{array}{l}\text { kasus korupsi penggelapan dana } \\
\text { rakyat dalam APBD sebesar Rp. } \\
119 \text { miliar dan menerima suap } \\
\text { Rp. } 10,5 \text { miliar dari pemilik Bank } \\
\text { Perkreditan Rakyat, Tripanca } \\
\text { Setiadana, pada } 2005 \text {. }\end{array}$ \\
\hline 10 & Fauzi Siin & Bupati Kerinci & Terpidana & Kasus suap dana APBN 2008 \\
\hline 11 & $\begin{array}{l}\text { John Manuel } \\
\text { Manoppo }\end{array}$ & Walikota Salatiga & Tersangka & $\begin{array}{l}\text { Kasus korupsi proyek } \\
\text { pembangunan Jalan Lingkar } \\
\text { Selatan Salatiga. }\end{array}$ \\
\hline 12 & Rusli Zaenal & Gubernur Riau & Tersangka & $\begin{array}{l}\text { Pembahasan peraturan daerah } \\
\text { yang berkaitan dengan } \\
\text { pemberian suap terhadap M. } \\
\text { Faisal Aswan dan M. Dunir, } \\
\text { anggota Dewan Perwakilan } \\
\text { Rakyat Daerah Riau. }\end{array}$ \\
\hline
\end{tabular}

Sumber: Purnomo, Danni, dan Eko 2013) 
Setelah mendapatkan perahu, seorang calon kepala daerah harus merogoh kocek dalamdalam. Ia harus membiayai sosialisasi, biaya kampanye, dan tim sukses dan tim pemenangan Pemilu, dan yang paling mahal adalah biaya pemasangan iklan baik di media cetak maupun elektronik. Tujuannya adalah agar bisa dikenal atau gampang oleh masyarakat luar. Dalam artikel Pilkada dan Pemekaran Daerah dalam Demokrasi Lokal di Indonesia: Local Strongman dan Roving Bandits yang ditulis Leo Agustinino dan Muhammad Agus Yusuf, Fitriyah mengutip sebagai berikut (Fitriyah 2012):

"Untuk membiayai itu semua (mendanai pelbagai biaya aktiviti kempen, biaya menyewa pakar political marketing, biaya untuk membangun sarana fisik di kantungkantung undi, biaya image building dan image bubbling (pensuksesan diri calon) dan banyak lagi), banyak calon yang tidak memiliki cukup dana. Maka dari itu, calon kepala daerah acap kali mencari para pengusaha untuk bergabung sebagai 'investor politik. Sebagai imbalan investasi atas keikutsertaan mereka (sebagai pelabur/ investor politik) dalam menjayakan calon dalam pilkada, maka para pengusaha dijanjikan akan mendapat banyak hak istimewa (perlindungan ekonomi dan politik)."

Tingginya biaya politik dalam pelaksanaan Pemilihan Kepala Daerah ini sangat paradoks dengan prinsip tata pemerintahan yang baik (good governance). Salah satu prinsip normatif yang harus dipenuhi adalah efisiensi. Menurut Marijan (2010), penyebab mahalnya biaya politik itu disebabkan oleh dua faktor. Pertama, desain pemilihan pejabat-pejabat publik didesain seperti mekanisme pasar. Persaingan dibuat sangat terbuka. Akibatnya pola ini memiliki konsekuensi. Para calon pejabat publik harus mengeluarkan dana yang tidak sedikit untuk mendongkrak perolehan suara.

Kedua, berkaitan dengan perilaku memilih. Pilkada menghasilkan perilaku pemilih yang rasional. Akan tetapi, kelompok pemilih rasional itu dibagi menjadi dua kelompok. Kelompok pertama adalah pemilih yang rasional karena memilih berdasarkan program yang ditawarkan oleh para calon kepala daerah. Kelompok ini terjadi pada orang-orang yang memiliki pendidikan, dan pemahaman di samping itu secara ekonomi sudah mapan. Kelompok ini masuk dalam ketegori kelas menengah ke atas. Sedangkan kelompok kedua, adalah pemilih rasional materil. Yaitu kelompok pemilih yang menentukan pilihannya berdasarkan pertimbangan-pertimbangan jangka pendek, seperti karena uang atau barang. Menurut Ketua Bawaslu RI Muhammad kelompok ini disebut "Golput" akronim dari Golongan Pencari Uang Tunai (Aritonang 2014). Kelompok ini tidak hanya menerima uang dari salah satu pihak saja, akan tetapi dari pihak-pihak yang lain.

Maraknya "Golput" bisa jadi karena lemahnya regulasi dalam mengatur dana kampanye para calon. Para calon yang bersaing dalam Pilkada bsa leluasa melakukan money politic. Praktik ini tumbuh subur. Tidak ada larangan ketat yang mengatur mengenai hal ini. Dan masyarakatt sebagai calon pemilih pun menganggapnya sebagai kewajaran. Pada diri mereka tidak memiliki pikiran akan bahaya dari politik uang, sehingga perilaku itu harus dijauhi (Fitriyah 2012). Tidak ada kasus politik uang yang masuk atau diproses secara hukum. Sejumlah alasan menjadi dalih, misalnya tidak cukup bukti, atau pelaporan sudah kedaluarsa.

\section{Konflik Hasil Pilkada}

Terjadinya perselisihan hasil Pilkada adalah hal yang wajar. Secara normatif, negara pun menyediakan institusi-institusi yang berwenang untuk menangani perselisihan tersebut khususnya bagi para justice seeker (pencari keadilan). 
Tabel 2.

Kelemahan Pengaturan Dana Kampanye Pilkada UU No. 32 Tahun 2004 tentang Pemerintah Daerah dan PP No. 6 Tahun 2005 tentang Pemilihan, Pengesahan Pengangkatan, dan Pemberhentian Kepala Daerah Dan Wakil Kepala Daerah

\begin{tabular}{|c|c|c|c|}
\hline No. & $\begin{array}{c}\text { Prinsip-prinsip } \\
\text { Pengaturan Dana } \\
\text { Politik } \\
\end{array}$ & Pengaturan & Permasalahan \\
\hline 1 & Sumber Dana & $\begin{array}{l}\text { Pasal } 83 \text { UU 32/2004 } \\
\text { Pasal } 83 \text { UU 12/2008 } \\
\text { Pasal } 65 \text { PP 6/2005 }\end{array}$ & $\begin{array}{l}\text { Tidak disebutkan sumbangan dari parpol } \\
\text { sebagai badan hukum atau perseorangan }\end{array}$ \\
\hline 2 & $\begin{array}{l}\text { Batasan jumlah } \\
\text { sumbangan }\end{array}$ & $\begin{array}{l}\text { Pasal } 83 \text { UU } 32 / 2004 \\
\text { Pasal } 83 \text { UU 12/2008 } \\
\text { Pasal } 65 \text { PP 6/2005 }\end{array}$ & $\begin{array}{l}\text { - Tidak ada batasan jumlah sumbangan } \\
\text { dari pasangan calon (paslon) } \\
\text { - Tidak ada batasan sumbangan dalam } \\
\text { bentuk bukan cash (in kind) yang } \\
\text { diterima/disetujui oleh paslon } \\
\text { - Tidak ada batasan jumlah sumbangan } \\
\text { dari parpol pendukung } \\
\text { - Tidak ada ketentuan rinci mengenai } \\
\text { apakah sebuah konglomerasi dapat } \\
\text { menyumbang lewat induk perusahaan } \\
\text { dan anak-anak perusahaan } \\
\text { - Tidak ada ketentuan soal utang }\end{array}$ \\
\hline 3 & $\begin{array}{l}\text { Pencatatan serta } \\
\text { pelaporan rekening } \\
\text { khusus dana } \\
\text { kampanye }\end{array}$ & $\begin{array}{l}\text { Pasal } 83 \text { UU 32/2004 } \\
\text { Pasal } 84 \text { UU 12/2008 } \\
\text { Pasal } 65 \text { dan } 68 \text { PP } \\
6 / 2005\end{array}$ & $\begin{array}{l}\text { - Tidak dijelaskan kapan rekening khusus } \\
\text { dana kampanye dibuka yang diatur } \\
\text { hanya ketentuan mengenai kapan } \\
\text { daftar penyumbang dilaporkan ke } \\
\text { KPUD. } \\
\text { - Tidak ada ketentuan mengenai saldo } \\
\text { awal untuk rekening dana kampanye } \\
\text { - Tidak dijelaskan berapa jumlah } \\
\text { rekening dana kampanye yang harus } \\
\text { dibuat dan apakah semua penerimaan } \\
\text { dana kampanye harus dicatat dalam } \\
\text { satu rekening atau ada pemisahan } \\
\text { antara rekening partai pendukung, } \\
\text { kandidat dan tim kampanye } \\
\text { - Tdak ada kewajiban pencatatan } \\
\text { pengeluaran } \\
\text { - Tidak dijelaskan secara rinci identitas } \\
\text { penyumbang (apa saja keterangan } \\
\text { penyumbang yang harus dicantumkan) } \\
\text { dan kategori penyumbang yang tidak } \\
\text { jelas identitasnya } \\
\text { - Jumlah 2,5 juta sebagai batasan } \\
\text { minimum pencatatan penerimaan } \\
\text { terlalu besar dan dapat mendorong } \\
\text { manipulasi dalam bentuk memecah } \\
\text { jumlah sumbangan menjadi bagian - } \\
\text { bagian yang jumlahnya lebih kecil dari } \\
\text { batasan minimum kewajiban mencatat }\end{array}$ \\
\hline
\end{tabular}




\begin{tabular}{lll}
\hline Mekanisme & Pasal 83 dan 84 UU & - Tidak ada sanksi terhadap temuan hasil \\
akuntabilitas & $32 / 2004$ & audit jika bermasalah \\
publik & Pasal 84 UU 12/2008 & - Tidak ada ketentuan mengenai syarat \\
& Pasal 65, 66 dan 67 PP & $\begin{array}{l}\text { kantor akuntan public yang dapat } \\
\text { 6/2005 }\end{array}$ \\
& ditunjuk oleh KPUD \\
& - Jarak waktu sejak diserahkan hingga \\
& diumumkannya hasil audit terlalu lama \\
& (23 hari setelah pemungutan suara) \\
& - Tidak dijelaskan mengenai media yang \\
& akan digunakan oleh KPUD dalam \\
& mengumumkan hasil audit kampanye \\
\hline
\end{tabular}

Sumber: Fitriyah (2012, dikutip dari Badoh 2010, 3-4)

Tabel 3.

Perbandingan UU 32 tahun 2004 dengan UU No. 12 Tahun 2008 terkait Sengketa Perselisihan Hasil Pilkada

\begin{tabular}{|c|c|c|}
\hline Dasar Hukum & UU No. 32 Tahun 2004 & UU No. 12 Tahun 2008 \\
\hline Institusi & $\begin{array}{l}\text { Pengadilan Tinggi untuk kabupaten/kota dan } \\
\text { Mahkamah Agung untuk tingkat provinsi. }\end{array}$ & $\begin{array}{l}\text { MK sebagai lembaga pertama dan } \\
\text { terakhir }\end{array}$ \\
\hline Subyek Perselisihan & Peserta Pemilu dengan KPUD & Peserta Pemilu dengan KPUD \\
\hline \multirow[t]{3}{*}{ Objek Perselisihan } & $\begin{array}{l}\text { Hasil penghitungan suara yang } \\
\text { mempengaruhi terpilihanya pasangan calon. }\end{array}$ & $\begin{array}{l}\text { Hasil penghitungan suara ditetapkan } \\
\text { oleh Termohon (KPUD) yang } \\
\text { mempengaruhi: }\end{array}$ \\
\hline & & $\begin{array}{l}\text { a. Penentuan pasangan calon yang } \\
\text { dapat mengikuti putaran kedua } \\
\text { Pilkada }\end{array}$ \\
\hline & & $\begin{array}{l}\text { b. Terpilihnya pasangan calon } \\
\text { sebagai kepala daerah dan wakil } \\
\text { kepala daerah. }\end{array}$ \\
\hline $\begin{array}{l}\text { Limit waktu pengajuan } \\
\text { permohonan }\end{array}$ & $\begin{array}{l}3 \text { hari setelah penetapan hasil pemilihan } \\
\text { kepala daerah dan wakil kepala daerah oleh } \\
\text { KPUD }\end{array}$ & $\begin{array}{l}3 \text { hari kerja setelah penetapan hasil } \\
\text { pemilihan kepala daerah dan wakil } \\
\text { kepala daerah oleh KPUD }\end{array}$ \\
\hline Limit waktu persidangan & $\begin{array}{l}\text { Empat belas hari sejak diterimanya } \\
\text { permohonan }\end{array}$ & $\begin{array}{l}14 \text { hari kerja sejak permohonan } \\
\text { dicatat dalam buku registrasi }\end{array}$ \\
\hline
\end{tabular}

Mahalnya biaya yang harus dikeluarkan oleh calon yang bertarung dalam Pilkada, ini berdampak terhadap kondisi psikologis calon. Rerata mereka yang kalah dalam bertarung, tidak siap dengan kekalahannya itu. Untuk itu, mereka akan menggunggat setiap hasil perolehan suara yang telah ditetapkan oleh KPU. Meski sebelum pelaksanaan pemilu, para kandidat ini menandatangani siap menang dan siap kalah akan tetapi dalam pelaksanaannya, para calon yang kalah akan menggugat ke tempat yang memungkinkan gugatannya itu bisa diterima. Peluang pengaduan yang memungkinkan adalah ke MA, Mahkamah Konstitusi, dan belakangan ke Dewan Kehormatan Penyelenggara Pemilu (DKPP). Lebih 90 Persen Pilkada berakhir di Mahkamah Konstitusi, 144 pasangan calon mendaftar gugatan (Paat 2015; Tim Liputan Sayangi.com 2013). 
Tabel. 4.

Konflik Pilkada Langsung

\begin{tabular}{|c|c|c|c|c|c|}
\hline \multirow{3}{*}{ Lokasi \& Tahun } & \multicolumn{5}{|c|}{ Hasil Pilkada } \\
\hline & & & & Perbedaan & \\
\hline & & Pasangan Calon & Jumlah & $\begin{array}{c}\text { Angka/ } \\
\text { Persentase }\end{array}$ & Dampak \\
\hline \multirow{3}{*}{$\begin{array}{l}\text { Kab. Tuban } \\
2006\end{array}$} & 1 & Haeny Relawati Rini & 327.805 & \multirow[t]{3}{*}{22.245 suara } & \\
\hline & & $\begin{array}{l}\text { Widyastuti \& Lilik } \\
\text { Soeharjono (Heli) }\end{array}$ & $(51,75 \%)$ & & \\
\hline & 2 & $\begin{array}{l}\text { Noor Nahar \& Go } \\
\text { Tjong Ping (Nonstop) }\end{array}$ & $\begin{array}{l}305.560 \\
(48,25 \%)\end{array}$ & & \\
\hline \multirow[t]{2}{*}{$\begin{array}{l}\text { Kab. Kaur } \\
\text { Bengkulu) }\end{array}$} & 1 & $\begin{array}{l}\text { Syaukani Saleh \& } \\
\text { Warman Suwardi }\end{array}$ & $\begin{array}{l}17.268 \\
(36,9 \%)\end{array}$ & \multirow[t]{2}{*}{$0,7 \%$. suara } & \multirow{2}{*}{$\begin{array}{l}\text { Perbedaan yang tipis } \\
\text { menyebabkan terjadinya } \\
\text { perbedaan persepsi dari calon } \\
\text { yang kalah atas hasil Pilkada }\end{array}$} \\
\hline & 2 & $\begin{array}{l}\text { Zulkifli Salam \& } \\
\text { Sahian Sirad }\end{array}$ & $\begin{array}{l}16.968 \\
(36,2 \%)\end{array}$ & & \\
\hline \multirow[t]{2}{*}{$\begin{array}{l}\text { Provinsi Maluku } \\
\text { Utara }\end{array}$} & 1 & $\begin{array}{l}\text { Thaib Armayn \& } \\
\text { Abdul Ghani Kasuba }\end{array}$ & $\begin{array}{l}179.020 \\
(37,35 \%)\end{array}$ & & \multirow[b]{2}{*}{$\begin{array}{l}\text { Terhadap hasil tersebut, KPU } \\
\text { Pusat membatalkan keputusan } \\
\text { KPUD karena perhitungan } \\
\text { dilakukan tertutup dan oleh Ketua } \\
\text { dan Anggota KPUD Maluku Utara } \\
\text { yang diberhentikan oleh KPU. } \\
\text { Dalam perhitungan suara yang } \\
\text { dilakukan KPU, pasangan Abdul } \\
\text { Gafur dan Abdur Rahim Fabanyo } \\
\text { justru memperoleh suara } \\
\text { terbanyak. }\end{array}$} \\
\hline & 2 & $\begin{array}{l}\text { Abdul Gafur \& Abdur } \\
\text { Rahim Fabanyo }\end{array}$ & $\begin{array}{l}179.020 \\
(37,35)\end{array}$ & & \\
\hline \multirow[t]{2}{*}{$\begin{array}{l}\text { Provinsi } \\
\text { Sulawesi } \\
\text { Selatan }\end{array}$} & 1 & $\begin{array}{l}\text { Syahrul Yasin Limpo- } \\
\text { Agus Arifin Nu'mang }\end{array}$ & $\begin{array}{l}1.432 .572 \\
(39,53 \%)\end{array}$ & \multirow[t]{2}{*}{$0,77 \%$} & \multirow{2}{*}{$\begin{array}{l}\text { Putusan MA menganulir } \\
\text { Keputusan KPUD yang } \\
\text { menetapkan Syahrul Yasin Limpo- } \\
\text { Agus Arifin Nu'mang sebagai } \\
\text { pemenang Pilkada. Akibatnya } \\
\text { putusan tersebut memicu konflik } \\
\text { di antara dua kubu yang kebetulan } \\
\text { berbeda etnis. Syahrul Yasin Limpo } \\
\text { yang beretnis Makasar dan Amin } \\
\text { Syam beretnis Bugis. }\end{array}$} \\
\hline & 2 & $\begin{array}{l}\text { Amin Syam-Mansyur } \\
\text { Ramli (Asmara) }\end{array}$ & $\begin{array}{l}1.404 .910 \\
(38,76 \%)\end{array}$ & & \\
\hline
\end{tabular}

Sumber: diolah dari Moch. Nurhasim $(2010,110)$.

Penanganan perselisihan hasil pemilihan kepala daerah antara Undang-Undang No. 32 Tahun 204 dengan Undang-Undang No. 12 Tahun 2008 terkait institusi yang berwenang terjadi perbedaan. Perbandingan tersebut bisa dilihat dalam Tabel 3.

Menurut Moch. Nurhasim, hasil Pilkada dan berakhir gugatan kerap kali disebabkan oleh perbedaan yang tipis yang menyebabkan adanya ketidakpuasan pasangan calon yang kalah bersaing. Disamping itu, massa gampang dikerahkan oleh para elit lokal yang bersaing. Contohnya adalah yang terjadi pada pelaksanaan Pilkada di Kabupaten Tuban, Kabupaten Kaur Bengkulu, Provinsi Maluku Utara, dan Provinsi Sulawesi Selatan. Dalam kasus Pilkada Tuban, perbedaan angka yang tipis menyebabkan massa yang calonnya kalah marah dan kemudian melakukan tindakan anarkis seperti pembakaran gedung KPUD, kantor bupati, rumah bupati, dan hotel 
milik bupati. Konflik serupa juga terjadi di Sulawesi Selatan antara kedua kubu Sharul Yasin Limpo dan Amin Syam (Nurhasim 2010). Konflik ini mengarah pada konflik etnis Syahrul Yasin Limpo yang beretnis Makasar dan Amin Syam beretnis Bugis.

\section{Pendaftaran Pemilih}

Hak memilih merupakan hak politik bagi setiap warga negara yang harus dihormati oleh setiap orang. Artinya, setiap pihak termasuk negara di dalamnya, tidak boleh menghalangi, membatasi daa menghapus hak-hak konstitusional seorang warga negara. Penghalangan atau pembatasan merupakan termasuk kategori pelanggaran hak asasi manusia.

Hak memilih mendapatkan pengakuan hukum yang diatur dalam Deklarasi Universal Hak Asasi Manusia (DUHAM). Pada pasal 21 DUHAM menyatakan: (1) Setiap orang berhak turut serta dalam pemerintahan negerinya sendiri baik dengan langsung maupun dengan perantara wakil-wakil yang dipilih secara bebas; (2) Setiap orang berhak atas kesempatan yang sama untuk diangkat dalam jabatan pemerintahan negerinya; (3) Kemauan rakyat harus menjadi dasar kekuasaan pemerintah.

Hak pilih juga mendapatkan jaminan oleh Undang-Undang Dasar 1945 pasal 27 ayat (1) bahwa setiap warga negara bersamaan kedudukannya di dalam hukum dan pemerintahan dan wajib menjunjung hukum dan pemerintahan itu dengan tidak ada kecualinya. Selanjutnya, pasal 28D ayat (1) menerangkan bahwa Setiap orang berhak atas pengakuan, jaminan, perlindungan, dan kepastian hukum yang adil serta perlakuan yang sama di hadapan hukum. Pada ayat berikutnya (3) berbunyi, "Setiap warga negara berhak memperoleh kesempatan yang sama dalam pemerintahan."

Lebih detail, Pasal 43 Undang-Undang No. 39 Tahun 1999 tentang Hak Asasi Manusia Pasal 43 menerangkan," Setiap warga negara berhak untuk dipilih dan memilih dalam pemilihan umum berdasarkan persamaan hak melalui pemungutan suara yang berlangsung, umum, bebas, rahasia, jujur, dan adil sesuai dengan ketentuan perundang-undangan." Mahkamah Konstitusi juga memberikan kepastian akan jaminan hak pilih setiap warga negara. Putusan No.011-017/PUU-I/2003 menerangkan bahwa hak konstitusional warga negara untuk memilih dan dipilih adalah hak yang dijamin konstitusi, undang-undang, maupun konvensi internasional sehingga pembatasan penyimpangan dan penghapusan hak akan hak tersebut adalah pelanggaran terhadap hak asasi manusia.

Akan tetapi, dari pelaksanaan Pemilu ke Pemilu permasalahan daftar pemilih ini selalu muncul. Masalah yang sering dijumpai adalah tidak datanya calon pemilih, hal ini disebabkan oleh migrasi atau mobilisasi calon pemilih (voters), pemilih ganda, orang yang tidak berhak seperti anggota TNI, dan Polri masih terdaftar, sebaliknya orang yang yang berhak didaftar malah tidak terdaftar. Uniknya lagi, ada orang yang sudah meninggal akan tetapi terdaftar dalam daftar pemilih tetap. Masalah ini menjadi dampak terhadap ketidakakuratan jumlah dalam daftar pemilih tetap (DPT).

Ketidakakuratan daftar pemilih disebabkan oleh sejumlah hal. Seperti temuan Hadar Nafis Gumay dkk dalam pelaksanaan Pilkada di Sumatera Utara selama tahun 2005-2007, problematika yang kerap dijumpai soal DPT adalah sebagai berikut: Pertama, Waktu yang diperlukan untuk melakukan pendaftaran dirasa sangat terbatas. kedua, adanya sikap yang apatis dari warga. Ketiga, adanya ketidakjelasan letak kewenangan serta tanggung jawab dalam pendaftaran pemilih. Keempat, adanya unsur kesengajaan yang dilakukan oleh pihak-pihak tertentu tertutama calon incumbent untuk mengacaukan daftar pemilih. Kelima, tidak siapnya KPU daerah serta jajaran di bawahnya untuk melakukan perbaikan data pemilih dengan 
alasan terbatasnya jumlah personel dan anggaran untuk melakukan verifikasi data pemilih (Farchan dan Partono 2016).

\section{Netralitas Penyelenggara Pemilu}

Salah satu syarat negara yang demokratis adalah keterjaminan dalam proses maupun hasil berdasarkan sistem yang demokratis. Masyarakat atau para elit politik bersaing secara kompetitif serta mendapatkan kesempatan yang sama. Apabila penyelenggara Pemilu itu berpihak, sama dengan menciderai hasil Pemilu. Tindakan tersebut akan mengurangi legitimasi dari masyarakat. Untuk itu, penyelenggara Pemilu harus berintegritas (Asshiddiqie 2014). Kualitas hasil Pilkada langsung berada di pundak penyelenggara Pemilu. Meski demikian, pelanggaran-pelanggaran yang dilakukan oleh penyelenggara Pemilu tidak sedikit.

Tabel. 5

Modus-Modus Pelanggaran Penyelenggara Pemilu

\begin{tabular}{|c|c|c|}
\hline No. & Kategori & Deskripsi \\
\hline 1 & Vote manipulation & $\begin{array}{l}\text { Mengurangi, menambahkan, atau memindahkan perolehan } \\
\text { suara dari satu peserta Pemilu ke peserta Pemilu yang lainnya, } \\
\text { perbuatan mana menguntungkan dan atau merugikan peserta } \\
\text { Pemilu satu dengan lainnya. }\end{array}$ \\
\hline 2 & Bribery of officials & $\begin{array}{l}\text { Pemberian sejumlah uang atau barang atau perjanjian khusus } \\
\text { kepada penyelenggara Pemilu dengan maksud memenuhi } \\
\text { kepentingan pemberinya atau untuk menguntungkan dan atau } \\
\text { merugikan pihak lain dalam kepesertaan suatu Pemilu } \\
\text { (candidacy). }\end{array}$ \\
\hline 3 & Un-equal treatment & $\begin{array}{l}\text { Perlakuan yang tidak sama atau berat sebelah kepada peserta } \\
\text { Pemilu dan pemangku kepentingan. }\end{array}$ \\
\hline 4 & Infringement of the right to vote & Pelanggaran terhadap hak memilih warga negara dalam Pemilu. \\
\hline 5 & Vote and duty secrecy & $\begin{array}{l}\text { Secara terbuka membertahukan pilihan politiknya dan } \\
\text { menanyakan pilihan politiknya dan menanyakan pilihan } \\
\text { politiknya dalam Pemilu kepada orang atau pemilih. }\end{array}$ \\
\hline 6 & Abuse of power & $\begin{array}{l}\text { Memanfaatkan posisi jabatan dan pengaruh-pengaruhnya, baik } \\
\text { atas dasar kekeluarga, kekerabatan, otoritas tradisional atau } \\
\text { pekerjaan, untuk mempengaruhi pemilih lain atau penyelenggara } \\
\text { Pemilu demi mendapatkan keuntungan-keuntungan pribadi. }\end{array}$ \\
\hline 7 & Conflict of interest & Benturan kepentingan \\
\hline 8 & Sloppy work of election process & $\begin{array}{l}\text { Ketidakcermatan atau ketidaktepatan atau ketidakteraturan atau } \\
\text { kesalahan dalam proses Pemilu. }\end{array}$ \\
\hline 9 & Intimidation and violence & $\begin{array}{l}\text { Melakukan tindakan kekerasan atau intimidasi secara fisik } \\
\text { maupun mental. }\end{array}$ \\
\hline 10 & Broken or breaking of the laws & Melakukan tindakan atau terlibat dalam pelanggaran hukum. \\
\hline 11. & Absence of effective Legal Redies & $\begin{array}{l}\text { Kesalahan yang dapat ditoleransi secara manusiawi sejauh tidak } \\
\text { berakibat rusaknya integritas penyelenggaraan Pemilu, juga } \\
\text { hancurnya independensi dan kredibilitas penyelenggara Pemilu. }\end{array}$ \\
\hline 12. & The Fraud of voting day & $\begin{array}{l}\text { Kesalahan-kesalahan yang dilakukan penyelenggara Pemilu pada } \\
\text { hari pemungutan dan penghitungan suara. }\end{array}$ \\
\hline 13. & $\begin{array}{l}\text { Destroying neutrality, impertiality, dan } \\
\text { independent }\end{array}$ & $\begin{array}{l}\text { Bertindak netral dan tidak memihak terhadap partai politik atau } \\
\text { peserta Pemilu. }\end{array}$ \\
\hline
\end{tabular}

Sumber: Sardini (2015) 
Beragam pelanggaran-pelanggaran yang dilakukan oleh penyelenggara Pemilu. DKPP mengklasifikasi modus-modus pelanggaran yang dilakukan oleh penyelenggara Pemilu. Yaitu, modus melalaikan tugas pokok dan fungsi dalam penyelenggaraan Pemilu, penggunaan jabatan dan kewenangan secara salah, penyuapan, proses seleksi calon penyelenggara Pemilu di sejumlah jenjang, dan ketidakcermatan, ketidakprofesionalan, integritas, dan kredibilitas dalam penyelenggaraan Pemilu. Modus pelanggaran paling berat adalah keberpihakan atau netralitas, dan imparsialitas penyelenggara Pemilu.

Masalah netralitas penyelenggara Pemilu kerap mewarnai pelaksanaan Pilkada langsung. Dewan Kehormatan Penyelenggara Pemilu merilis bahwa sebanyak 75\% anggota KPU dan $24 \%$ anggota Panwas di daerah yang disidangkan di DKPP, disebabkan karena faktor netralitas (DKPP RI 2013, 28). Begitu juga pada tahun 2014, dari sebanyak 244 penyelenggara Pemilu yang diperiksa karena diduga melanggara kode etik, sebanyak 53 orang karena keberpihakan (DKPP RI 2014, 39). Hasil sidang pemeriksaan kode etik DKPP terhadap penyelenggara Pemilu tahun 2015, ada 25 perkara terkait dengan pelanggaran netralitas dan keberpihakan dari total 109 perkara yang disidangkan di DKPP. Selama Pilkada serentak tahun 2015, ada 24 penyelenggara Pemilu yang diberhentikan tetap dan empat orang yang diberhentikan sementara. Sejak tahun tahun 2012 hingga 2017, DKPP telah memberhentikan penyelenggara Pemilu sebanyak 424 orang. Hampir setengah dari penyelenggara yang diberhentikan tetap adalah terkait dengan sengketa Pilkada dan keberpihakan penyelenggara Pemilu dengan peserta Pemilu.

Tabel 6.

Modus-Modus Pelanggaran Kode Etik Penyelenggara Pemilu Tahun 2015

\begin{tabular}{clc}
\hline No. & \multicolumn{1}{c}{ Modus Pelanggaran } & Jumlah Perkara \\
\hline 1. & Manipulasi suara & 5 \\
2. & Penyuapan & 0 \\
3. & Perlakuan tidak adil & 11 \\
4. & Pelanggaran hak pilih & 0 \\
5. & Kerahasiaan suara dan tugas & 1 \\
6. & Penyalahgunaan kekuasaan & 7 \\
7. & Konflik kepentingan & 4 \\
8. & Kelalaian tugas pada proses Pemilu & 26 \\
9. & Intimidasi dan kekerasan & 2 \\
10. & Pelanggaran hukum & 17 \\
11. & Tidak adanya upaya hukum yang efektif & 10 \\
12. & Penipuan saat pemungutan suara & 0 \\
13. & Pelanggaran netralitas dan keberpihakan & 25 \\
14. & Konflik internal institusi & 1 \\
15. & Lain-lain & 0 \\
\hline & Total & 109 \\
\hline
\end{tabular}

Sumber: DKPP RI (2015). 


\section{Rawan Gugatan}

Pelaksanaan Pilkada langsung rawan terhadap gugatan, meski gugatan merupakan hak konstitusional warga negara dalam mencari keadilan khususnya para calon peserta Pilkada. Negara menyediakan sistem kerangka hukum Pemilu baik bagi mereka yang merasa dirugikan. Kerangka hukum Pemilu dirancang untuk mewujudkan pelaksanaan Pemilu yang berintegritas. Integritas Pemilu meliputi integritas proses/tahapan, integritas hasil-hasil Pemilu, dan integritas penyelenggara Pemilu. Kerangka Hukum Pemilu, terdiri atas: 1) Pelanggaran Administrasi Pemilu; 2) Pelanggaran Tindak Pidana Pemilu; 3) Pelanggaran Kode Etik Penyelenggara Pemilu; 4) Sengketa Administrasi Pemilu; 5) Sengketa Tata Usaha Negara Pemilu; dan 6) Perselisihan Hasil Pemilihan Umum (PHPU). Pelanggaran administrasi Pemilu diserahkan ke KPU, pelanggaran tindak pidana Pemilu ke pengadilan umum, pelanggaran kode etik penyelenggara Pemilu ke Dewan Kehormatan Penyelenggara Pemilu, dan Perselisihan hasil Pemilu ke Mahkamah Konstitusi, sengketa tata usaha negara Pemilu ke PTTUN (Sardini 2015; 2016).

Setiap kali pelaksanaan Pilkada, selalu berakhir dengan gugatatan. DKPP, dan Mahkamah Konstitusi kerap dijadikan sasaran bagi para pemburu kekuasaan, terlebih para calon yang kalah. Menurut Direktur Jenderal Otonomi Daerah (Otda) Djohermansyah Johan, lebih dari 90\% pelaksanaan Pilkada langsung berakhir di Mahkamah Konstitusi. Akibatnya, terjadi peralihan konflik yang terjadi selama Pilkada berpindah ke MK. PHPU yang telah ditangani sejak tahun 2008, MK sudah menangani 732 perkara. Yang paling banyak adalah di tahun 2010 lebih dari 300 perkara. Sementara tahun 2014, MK sudah menangani sebanyak 13 perkara. Praktik kecurangan dalam penyelesaian sengketa Pilkada di MK tersebut antara lain upaya membeli suara hakim sampai menghasut para pendukung kandidat.

Untuk mengurangi gugatan sengketa Pilkada di Mahkamah Konstitusi, MK sendiri mengeluarkan Peraturan Mahkamah Konstitusi. Untuk provinsi yang jumlah penduduknya di bawah 2 juta, syarat selisih suara adalah $2 \%$. Untuk provinsi dengan jumlah penduduk 2 juta sampai 6 juta, selisih suara 1,5\% dan 6 juta sampai 12 juta selisihnya $1 \%$ serta di atas 12 juta selisihnya 0,5\%. Sedangkan untuk kabupaten/kota, jumlah penduduk di bawah 150 ribu selisih suara yang bisa disengketakan adalah 2\%, 150 ribu sampai 250 ribu 1,5\%, 250 ribu sampai 500 ribu 1\% dan diatas 500 ribu selisihnya $0,5 \%$. Meski demikian, gugatan di Mahkan Konstitusi tetap banyak. Selama Pilkada serentak tahun 2015, sebanyak 144 pasangan calon yang mengadukan ke MK.

Selesai perkara sengketa di MK, belum tentu selesai masalah. Kandidat yang kalah bersaing di Pilkada yang masih belum puas akan melanjutkan gugatannya ke Dewan Kehormatan Penyelenggara Pemilu. Yang menjadi sasarannya adalah kode etik penyelenggara Pemilu. Selama Pilkada serentak tahun 2015, pengaduan dugaan pelanggaran kode etik penyelenggara Pemilu yang diterima DKPP sebanyak 247 perkara. Sedangkan jumlah Teradu 385 orang. Dari jumlah tersebut ada 24 penyelenggara Pemilu yang diberhentikan tetap, 4 orang yang diberhentikan sementara (DKPP RI 2015, 47-9).

\section{Simpulan}

Hasil Pilkada langsung telah menyumbang perkembangan positif terhadap daerah-daerah. Ada sejumlah daerah yang maju karena kreativitas dan inovatif dari pemimpin-pemimpinannya. Di samping itu, dengan adanya pemilihan kepala daerah langsung, setiap warga negara memiliki kesempatan yang sama untuk mencalonkan diri. Namun dampak dari Pilkada langsung pun cukup 
besar. Biaya pelaksanaan Pilkada sangat mahal baik bagi penyelenggaraan Pilkada mau pun bagi calon yang akan berkompetisi. Pelaksanaan Pilkada serentak pun tidak menjadi jaminan bahwa biaya pelaksanaan Pilkada menjadi semakin murah. Mahalnya biaya Pilkada ini diduga menjadi penyebab bagi kepala daerahkepala daerah yang tersandung hukum. Banyak kepala daerah yang menjadi berakhir di hotel prodeo akibat dari perilaku korupsi dengan beragam modus.

Untuk itu perlu adanya evaluasi terhadap pelaksanaan Pilkada langsung. Ada pun yang menjadi masukan sebagai evaluasi terhadap mekanisme pelaksanaan Pilkada adalah sebagai berikut: Alternatif pertama, pelaksanaan Pilkada menjadi dua yaitu Pilkada langsung dan Pilkada tidak langsung. Misalnya, untuk tingkat provinsi dan daerah yang berstatus kabupaten mekanisme pemilihan melalui tidak langsung.
Asumsinya adalah secara administrasi wilayah provinsi dan kabupaten luas. Sedangkan untuk daerah yang berstatus kota mekanisme pemilihan kepala daerah secara langsung. Asumsinya adalah selain jumlah penduduk yang relatif lebih sedikit, penduduk perkotaan lebih melek huruf. Pilkada tidak langsung jauh lebih hemat dibandingkan dengan Pilkada langsung. Tidak perlu KPU, maupun Bawaslu. Masyarakat mempercayakan aspirasi sepenuhnya kepada anggota legislatif daerah. Secara konstitusi, Pilkada tidak langsung pun demokratis.

Alternatif kedua, khusus pemilihan kepala daerah tingkat provinsi, dilaksanakan secara tidak langsung. Sedangkan untuk kepala daerah tingkat kabupaten dan kota dilakukan Pilkada langsung. Asumsinya wilayah kabuaten dan kota lebih bersentuhan langsung dengan masyarakat. Di samping itu, relasi calon kepala daerah dengan calon pemilih lebih dekat. []

\section{Daftar Pustaka}

Aritonang, Deytri Robekka. 2014. "Ketua Bawaslu: Ada Golput, Golongan Pencari Uang Tunai." https://nasional.kompas.com/read/2014/02/11/1808582/Ketua.Bawaslu.Ada.Golput.Golonga n.Pencari.Uang.Tunai (November 10,2016).

Asshiddiqie, Jimly. 2014. Menegakan Kode Etik Penyelenggara Pemilu. Jakarta: Rajawali Press.

Badoh, Ibrahim Zuhdhy Fahmi. 2010. Kajian Potensi-Potensi Korupsi Pilkada. Jakarta.

Dianto, Dianto. 2013. "Pemilihan Kepala Daerah secara Langsung oleh Rakyat dan melalui DPRD: Studi Komparatif dalam Telaah Yuridis." Fakultas Hukum Universitas Mataram. https://docplayer.info/7876-Jurnal-ilmiah-pemilihan-kepala-daerah-secara-langsung-olehrakyat-dan-melalui-dprd-studi-komparatif-dalam-telaah-yuridis.html.

DKPP RI. 2013. DKPP Outlook 2014: Refleksi dan Proyeksi. Jakarta.

—_. 2014. DKPP Outlook 2015: Refleksi dan Proyeksi. Jakarta.

__ 2015. DKPP Outlook 2016: Refleksi dan Proyeksi. Jakarta.

Farchan, Yusa', dan Partono Partono. 2016. "Problematika Pilkada Langsung; Studi Kasus Pelaksanaan Pilkada Langsung di Provinsi Sumatera Utara 2005-2007." Jurnal Renaissance 1(1): 33-48.

Fitriyah, Fitriyah. 2012. “Fenomena Politik Uang dalam Pilkada.” Politika:Jurnal Ilmu Politik3(1): 5-14. 
Haris, Syamsudin. 2003. Desentralisasi dan Otonomi Daerah: Desentralisasi, Demokratisasi dan Akuntabilitas Pemerintahan Daerah. Jakarta: LIPI kerjasama PGRI, dan AIPI.

2014. Masalah-Masalah Demokrasi Kebangsaan Era Reformasi. Jakarta:Yayasan Obor.

Koirudin. 2005. Menuju Partai Advokasi. Yogyakarta: Pustaka Tokoh Bangsa.

Maesarini, Indah Wahyu. 2016. "Otonomi Daerah di Indonesia: Keberhasilan atau Kegagalan Pemerintah?" http://www.stiami.ac.id/jurnal/download/66/otonomi-daerah-di-indonesia-:keberhasilan-atau-kegagalan-pemerintah.

Marijan, Kacung. 2010. “Demokrasi vs Efisiensi.” https://nasional.kompas.com/read/2010/12/23/ 03082518/demokrasi.vs.efisiensi.

Nurhasim, Moch. 2010. "Konflik dalam Pilkada Langsung: Studi tentang Penyebab dan Dampak Konflik." Jurnal Penelitian Politik 7(2): 105-17.

Paat, Yustinus. 2015. "144 Pasangan Calon Daftar Gugatan ke MK." https://www.beritasatu.com/ pilkada/335058-144-pasangan-calon-daftar-gugatan-ke-mk.html.

Purnomo, Wayan Agus, Danni, dan Eko. 2013. “Ini Daftar Kepala Daerah Tersandung Kasus Korupsi.” https://nasional.tempo.co/read/460207/ini-daftar-kepala-daerah-tersandung-kasuskorupsi/full\&view=ok.

Romli, Lili. 2008. "Evaluasi Pilkada Langsung di Indonesia." dalam Year Book 2007 - Democrazy Pilkada, ed. Pusat Penelitian Politik LIPI. Jakarta: Yayasan Obor Indonesia.

Sardini, Nur Hidayat. 2015. Mekanisme Penyelesaian Pelanggaran Kode Etik Penyelenggara Pemilu. Jakarta: LP2AB.

___ 2016. "Rapat Koordinasi Evaluasi Sentra Gakumdu."

Subroto, dan Chairul Akhmad. 2013. "Meraih Berkah Otonomi Daerah." Republika Online. https://www.republika.co.id/berita/nasional/politik/13/08/01/mqt8g8-meraih-berkahotonomi-daerah.

Sumanto, Ign. 2004. Pemilihan Presiden Secara Langsung 2004: Dokumentasi, Analisa dan Kritik Jakarta: Ristek-CSIS.

Tim Liputan Kompas. 2010. “Biaya Pilkada Rp 15 Triliun.” https://nasional.kompas.com/read/ 2010/07/24/03414390/twitter.com.

Tim Liputan Sayangi.com. 2013. "Lebih 90 Persen Pilkada Berakhir di MK." https://www.sayangi.com/ 2013/11/18/11033/news/lebih-90-persen-pilkada-berakhir-di-mk.

Zainuddin, Muhammad. 2015. Isu, Problematika, dan Dinamika Perekonomian, dan Kebijakan Publik: Kumpulan Essay, Kajian dan Hasil Penelitian Kuantitatifdan Kualitatif. Yogyakarta: Deepublish. 